\title{
Strah od bolesti i smrti - od variola virusa nekad do COVID-19 danas
}

\section{Željko Cvetnic ${ }^{*}$}

\section{Sažetak}

Bolesti su kroz čitavu povijest imale veliki utjecaj na razvoj i prosperitet čovječanstva, pobuđivale su pozornost zbog masovnosti pojave, velike smrtnosti među oboljelima i dalekosežnih posljedica koje su prouzročile. Zbog straha od gubitka zdravlja i nestanka života, bolest i smrt oduvijek su bile čovjekove bitne preokupacije. Velike epidemije su tijekom povijesti odlučivale o sudbini pojedinih naroda, slabile su snagu moćnih i velikih sila, prouzročile glad i bijedu. Epidemije velikih boginja, kuge, malarije, sifilisa, kolere, pjegavog tifusa, lepre i tuberkuloze obilježile su povijesti i bile su stalni pratitelj stradanja, nesreća i patnji ljudi tijekom minulih stoljeća. U XX. stoljeću „španjolska gripa - majka svih pandemija“ obilježila je početak stoljeća, a pred kraj tog stoljeća pojava AIDS-a, svojom pojavom i posljedicama prestrašila je svijet. I u novom tisućljeću bolesti predstavljaju veliku i stalnu prijetnju današnjem društvu i dalje su jedan od najvećih ubojica $u$ svijetu. Danas od zaraznih bolesti godišnje umire približno 15 milijuna ljudi. Pojava pandemije s COVID-19, najveće epidemije u XXI. stoljeću u iznimno kratkom vremenu promijenila je svijet i svijet je na koljenima. Ne mimoilazi ni bogate i svjetski snažne države ni državnike. Taj strah svakako postaje veći o opravdaniji kada Svjetska zdravstvena organizacija napominje da je čovječanstvo u ozbiljnoj i strašnoj opasnosti. Jedno je sigurno, a to je da nas pojava epidemije različitih bolesti potakne na duboko razmišljanje o budućnosti koja u tom slučaju postaje neizvjesna, remeti naše planove, korigira i usporava ciljeve.

Ključne riječi: bolest, smrt, epidemija, variola virus, COVID-19

\section{Uvod}

Povijest svijeta isprepletena je utjecajem različitih zaraznih bolesti na ljudsku populaciju. Spoznaja o vlastitoj ili bolesti bliskih ljudi, mijenja psihu svakog čovjeka. Reakcije ljudi prema bolestima su vrlo različite; neki kreću u borbu protiv bolesti, traže pomoć ili utjehu, neki padnu u

depresiju, a drugi utjehu nalaze u molitvi i Božjoj pomoći. Bolest nas potiče na duboko razmišljanje o budućnosti koja je u tom slučaju neizvjesna, remeti nam planove, korigira i usporava nam ciljeve.

Zbog straha od gubitka zdravlja i nestanka života, bolest i smrt oduvijek su

Dr. sc. Željko CVETNIĆ*, dr. med. vet., akademik, (dopisni autor, e-mail: cvetnic@veinst.hr), Veterinarski zavod Križevci, Hrvatski veterinarski institut, Hrvatska 
bile bitne preokupacije ljudi. Strah od bolesti je sigurno jedan od najstarijih strahova, a već je u Svetom pismu opisano da bolesnog čovjeka društvo u potpunosti odbacuje i stigmatizira (Dodig, 2016.). Velike epidemije koje su nekada prouzročile smrt stotine milijuna ljudi, poput uzročnika velikih boginja, suzbile su se cijepljenjem; druge, poput uzročnika kuge, liječe se antibioticima, dok neke još traju kao što su: tuberkuloza, malarija i kolera. Epidemije poput AIDS-a, koje su se pojavile kasnije, prouzročile su veliki pobol i više milijunsku smrtnost, ali se na neki način drže pod kontrolom. Pojava bolesti, poput SARS-a (engl. Severe acute respiratory syndrome) 2002. godine u Kini, ili MERSa (engl. Middle east respiratory syndrome) u zemljama Bliskog istoka 2012. godine te ebole u zapadnoj Africi 2014., i mnoge druge u početku pobude pozornost stručnjaka i medija, ali vrlo malo nas običnih ljudi iz razloga, jer smatramo da je to geografski jako daleko od nas, osobito od nas koji pripadamo zapadnom dijelu svijeta (Cvetnić, 2019.).

Bolest predstavlja novost te mnogi detalji nisu poznati što pojačava osobni doživljaj opasnosti. Panika predstavlja intenzivan, odnosno jak doživljaj straha, a strah može biti reakcija na stvarnu ili pretpostavljenu prijetnju, koju očekujemo i percipiramo na temelju naše osobne procjene ili doživljaja rizika. Strah i tjeskoba, a s tim u vezi i naše ponašanje, često nije odraz stvarnog rizika utemeljenog na epidemiološkim podatcima već odraz našeg osobnog doživljaja rizika ili opasnosti (Muslić, 2020.).

Takva je situacija bila i s pojavom koronavirusne bolesti (COVID-19, engl. coronavirus disease 2019) prouzročena novim koronavirusom nazvanim SARS-CoV-2 u Kini krajem 2019. godine. I tada je navedena pojava bolesti zaokupila pažnju stručnjaka, medija, ali kad su se početkom 2020. godine pojavili prvi slučajevi bolesti i u Europi, a zatim krajem veljače i u Hrvatskoj, došlo je do panike i straha među ljudima od moguće zaraze. Došlo je do stvaranja zaliha hrane i raznih kućnih i općih potrepština, napada na strance, a osobito one koji dolaze iz žarišta bolesti u strahu da nas ne zaraze. U ovom radu želio sam ukratko prikazati koliki su utjecaj imale najopasnije zarazne bolesti te koliku su bol, patnju, strah i smrtnost nanosile ljudima tijekom povijesti. Tema je posebno aktualna sada $\mathrm{u}$ jeku pandemije prouzročene koronavirusom (SARSCov-2) najveće epidemije 21. stoljeća, kad većina ljudi u nas i svijetu živi u strahu od COVID-19.

\section{Bolest i strah}

Bolest (lat. morbus - zlo, bolest, nemoć, nezdravost, bolesno stanje organizma) je određeni poremećaj s prepoznatljivim simptomima i znacima, bilo kao tjelesna anomalija ili oštećenje funkcije, može zahvatiti cijelo tijelo ili samo dio, a uzrok može ili ne mora biti poznat. Za bolest kažu da je promjena čitavog tijela nagore (Marević, 2000., Anonymous, 2006.).

Prema raspravama koje su pripisivane Hipokratu (460. - 377. pr. Kr.), bolest predstavlja gubitak prirodnog sklada, odstupanje od pravila, narušavanje idealnog odnosa medu dijelovima skladne cjeline. To je prema Hipokratu opći i lokalni poremećaj između četiri temeljna soka ljudskog tijela (krvi, sluzi, žute žuči i crne žuči). Zdravlje je skladan raspored temeljnih sokova, a bolest je nedostatak sokova i njihove neravnoteže. Broj bolesti je neograničen jer postoji beskraj mogućnosti i neravnoteža između sokova tijela (Grmek, 2000.).

Strah uz radost, ljutnju i žalost spada u najvažnije emocije tzv. "primarne emocije $^{\prime \prime}$. Svi ljudi, više ili manje, u svim razdobljima života doživljavaju navedene emocije. Smatra se da je strah jedan od najstarijih afekata koji pripada instinktu zaštite od opasnosti kao prvobitna biološka alarmantna reakcija. Mnogi nam citati o tome govore, poput: „Čovjek je biće 
koje se plaši“, „Bez straha ni jedna vrsta ne bi preživjela. Strah je u nama i prati nas čitavog našeg života". Strah isto tako sprječava da što više iskoristimo sve svoje sposobnosti, a može ih i prigušiti. Ili kako Ivo Andrić kaže: „Strah nam koči pamet i vezuje ruke". Jean Paul Sartre navodi: „Svi se ljudi plaše. Svi. Onaj koji se ne plaši nije normalan, to nema nikakve veze s hrabrošću". Potrebno se suočiti sa strahom, pogledati mu u oči, ublažiti tjeskobu i sve negativne posljedice koje strah stvara u čovjeku (Nikić, 1994.).

Zarazne bolesti su oduvijek pobuđivale najveću pažnju zbog masovnosti pojave, velike smrtnosti među oboljelima i dalekosežnih posljedica koje prouzroče. Čovjek je bolest prepoznavao kao slabost i nemoć tijela. Prikazane su jednostavnim opisima i uopćenim simptomima stoga je vrlo često teško odrediti o kojoj se bolesti radi. Bolesti su ugrožavale zdravlje, a one opasne i život, osobito ako su se pojavljivale kao epidemije. Velike epidemije su tijekom povijesti odlučivale o sudbini pojedinih naroda, slabile su snagu moćnih i velikih sila, prouzročile su glad i bijedu. O epidemijama zaraznih bolesti pisali su i pišu: liječnici, povjesničari i kroničari pa se iz njihovih zapažanja može saznati o patnjama čovječanstva kroz povijest. Već su stari kulturni narodi upoznali mnoge strahote zaraznih bolesti. Bolest, njihov nastanak i širenje u skladu su s medicinskim shvaćanjima toga vremena. Uglavnom postanak epidemija smatraju nadnaravnim uzrokom, a kasnije i Božjom kaznom (Glesinger, 1978.).

\section{Velike boginje}

Velike boginje spadaju u najsmrtonosnije i najstrašnije virusne bolesti $s$ kojima se čovječanstvo suočilo tijekom povijesti. Samo tijekom XX. stoljeća epidemije boginja prouzročile su smrt od 300 do 500 milijuna ljudi. Smatra se da su tijekom posljednjih tisuću godina odgovorne za smrt $10 \%$ ljudske popu- lacije širom svijeta (Theves i sur., 2014.). U Kini je već u X. stoljeću vršena prva zaštita od boginja upuhivanjem u nos praha sasušenih krasta skinutih s bolesnika oboljelih od boginja. Kasnije su se primjenjivali postupci variolizacije pa sve do cijepljenja virusom kravljih boginja koje je prvi primijenio Edward Jenner 1796. godine, a nakon toga je cijepljenje bio postupak koji se primjenjivao u cijelom svijetu (Behbehani, 1983.). Taj postupak je zaštitio čovječanstvo i pridonio kasnije značajnom demografskom rastu (Theves i sur., 2014.). Godine 1891. donesen je Zakon o cijepljenju stanovništva protiv boginja u Hrvatskoj i Slavoniji, kojim je određeno obvezno cijepljenje stanovništva protiv boginja (Rakovac, 1896.). Zakonom je određeno da se kao cjepivo rabi animalno cjepivo. Zbog toga je 1893. ustrojen Zemaljski cjepilišni zavod u Zagrebu u Gundulićevoj ulici 33. Voditelj Zavoda bio je dr. Fodor, a osim njega zaposlen je i kotarski veterinar Badovinac. Postupak proizvodnje započet je na teladi, a cjepne sojeve (vakcinija virusa) nabavili su najprije u Rotterdamu, a zatim u Linzu. Godine 1893. cijepili su 116 teladi i rasprodali 165257 doza cjepiva (Fodor, 1894.).

Polovicom XX. stoljeća boginje su bile znatno proširene $u$ svijetu, a $u$ mnogim zemljama i endemske. Tada je još uvijek obolijevalo od 10 do $15 \mathrm{mi}-$ lijuna ljudi širom svijeta, a umiralo je oko dva milijuna. Svjetska zdravstvena organizacija je 1967. donijela Program za suzbijanje velikih boginja. U sljedećih deset godina uz primjenu cijepljenja, posljednji slučaj velikih boginja zabilježen je 1977. godine u Somaliji, a 1980. godine SZO je proglasila svijet slobodnim od boginja. Boginje su prva i za sada jedina bolest na svijetu koju su ljudi suzbili cijepljenjem i drugim javno zdravstvenim mjerama. Velike boginje su usmrtile više ljudi na svijetu nego svi ratovi tijekom povijesti (Morse, 2009.). 
Najveća epidemija velikih boginja u Europi nakon Drugog svjetskog rata bila je 1972. godine u bivšoj Jugoslaviji. Epidemija se dogodila u razdoblju intenzivne kampanje u suzbijanju boginja u svijetu. Tijekom dva mjeseca oboljelo je 175 osoba, a 35 (20\%) ih je umrlo (Čobeljić, 2004.). Virus variole je u Jugoslaviju prenio hodočasnik s Kosova koji je još s 24 hodočasnika posjetio Meku i Medinu, a vraćali su se autobusom preko Iraka, posjećujući derviška mjesta oko Basre i Bagdada gdje je bilo oboljelih od boginja i gdje su se po svemu sudeći i zarazili (Kuljić-Kapuljica, 2004.). Pribjeglo se masovnom cijepljenju te je broj procijepljenih prema broju oboljelih bio otprilike pet puta veći nego u ijednoj prijašnjoj epidemiji variole, a pritom je potrošeno 18 milijuna doza cjepiva (Mlinarić-Galinović, 2013.).

U rod u koji spada i variola virus, uzročnik velikih boginja, spadaju vakcinija virus, virus majmunskih i kravljih boginja, virus boginja deva i druge vrste. Najnovije studije pokazuju da je u budućnosti moguće očekivati evoluciju zoonotskih ortopoksvirusa i nastanak novog virusa sličnog variola virusu (Shchelkunov, 2013.). Još uvijek postoje uzorci virusa u laboratorijima u Rusiji i SAD. Kada bi se virus boginja koristio kao biološko oružje, posljedice bi mogle biti vrlo pogubne, jer već skoro 40 godina nitko nije cijepljen protiv boginja. Posljednji put je cjepivo upotrijebila američka vojska 1989. godine prije intervencije u Iraku. Za aktivnu imunizaciju protiv velikih boginja postoji cjepivo pod nazivom ACAM2000, odobreno u SAD-u, a proizvedeno je više od 200 milijuna doza za američke nacionalne strateške interese (Nalca i Zumbrune, 2010.).

\section{Španjolska gripa}

Pandemija gripe iz 1918. godine je jedna od paradigmi noćne more koja se pojavljuje kad se spominju smrtonosne zarazne bolesti. Španjolska gripa je po svemu sudeći bila najveća prirodna katastrofa početkom XX. stoljeća. Službene procjene smrtnosti koje je gripa prouzročila stalno rastu, jer istraživači i dalje pronalaze podatke $\mathrm{u}$ zemljama $\mathrm{u}$ razvoju i udaljenim mjestima (Morse, 2009.). Nakon pandemije španjolske gripe 1919. godine, smatralo se da umrlo oko 21,5 milijuna ljudi, a novije studije pokazale su da je prouzročila smrt od 50 pa čak do 100 milijuna ljudi. Procjenjuje se da je jedna trećina tadašnje svjetske populacije ili oko 500 milijuna ljudi bilo zaraženo i imalo klinički vidljive znakove bolesti. Zato španjolsku gripu i nazivaju "majkom svih pandemija" (Taubenberger i Morens, 2006.). Ni jedna pošast, ni jedan rat, ni jedno razdoblje gladi u ljudskoj povijesti nije nikada usmrtila toliko ljudi u tako kratkom razdoblju. Pandemija španjolske gripe iz 1918. godine je najveći globalni demografski potres koji je svijet ikada doživio. Španjolska gripa bila je u sjeni Prvog svjetskog rata, iako je odnio znatno manje ljudskih života (oko osam milijuna), veliki rat je trajao dulje, a posvećivala mu se i veća medijska pozornost. Javnost je gripu prihvaćala kao produžetak ratnih stradanja, a jedan od razloga je i što je svaki val španjolske gripe trajao razmjeno kratko $\mathrm{i}$ ona bi opet nekoliko mjeseci nestala (Anušić, 2015.). Pandemija španjolske gripe iz 1918. bila je toliko smrtonosna, a kada bi se ta bolest pojavila danas i usmrtila isti postotak američkog stanovništva, umrlo bi više od 1,5 milijuna Amerikanaca. U jednoj bi godini ubila više ljudi nego što ih svake godine umre od srčanih bolesti, tumora, moždanog udara, kroničnih plućnih bolesti, AIDS-a i Alzheimerove bolesti. Epidemija je utjecala na tijek povijesti, ubivši više Amerikanaca u jednoj godini nego što ih je umrlo $u$ bitkama $u$ Prvom i Drugom svjetskom, Korejskom i Vijetnamskom ratu (Kolata, 2001.). Španjolska se gripa može smatrati „povije- 
snom" nesrećom i okrutnom posljedicom velikog rata (Erkoreka, 2009.).

\section{Kuga, malarija i pjegavi tifus}

Vektori (komarci, krpelji, muhe, buhe, uši i drugi) su prenositelji različitih uzročnika transmisivnih (vektorskih) zaraznih bolesti s jedne zaražene osobe na drugu ili sa zaražene životinje na čovjeka. Jedna od najvažnijih transmisivnih (vektorskih) bolesti koju prenose komarci, a uzročnici malarije su protozoe. Uši prenose uzročnika pjegavog tifusa, rovovske groznice i rekurenthe (povratne) groznice. Kugu u prirodnim žarištima prenosi štakorska buha. Navedene bolesti obilježile su povijest jer su opisane od najranijih vremena poput malarije, kuge, a stalni pratititelji stradanja, nesreća i patnji ljudi tijekom ratovanja bio je i pjegavi tifus.

Kuga je jedna od najopasnijih bakterijskih bolesti. Smatra se da već dugo prati ljudski rod, a opisivana je još od antičkih vremena. U Svetom je pismu za sve nevolje koje je čovjek doživljavao, glad i kuga, to pripisano kazni za ljudske grijehe. Kuga je bila sinonim za bolest, nesreću i patnju. Od kuge se umiralo u strašnim mukama, a bila je i jedno od prokletstava (Dodig, 2016.). Epidemija kuge obilježila je čitavo razdoblje kasnog srednjeg i dio ranog srednjeg vijeka. Učinak kuge postaje značajan za povijest čovječanstva. Kroničar navodi da ,kuga nije poštedjela ni jedno mjesto, gdje boravi čovjek, ni otoka ni špilje, niti gorskog vrha..." (Meyer, 1961.). Uzročnik se održava među populacijom divljih glodavaca, vektor je štakorska buha, koja uzročnika širi među glodavcima. Kuga je odavno nestala iz Europe, ali i dalje tinja u žarištima diljem svijeta poput Azije, Afrike, Sjeverne i Južne Amerike. Kuga se ne može iskorijeniti jer je široko rasprostranjena $\mathrm{u}$ prirodnim rezervoarima. Pokazuje se u mnogim slučajevima da je ona re-emergen- tna bolest, koja se nakon mnogo godina ponovno javlja te i dalje predstavlja prijetnju javnom zdravstvu mnogih zemalja (Cvetnić, 2014.).

Malariju su nazivali kraljicom bolesti, a poznata je od pamtivijeka. Zauzima jedinstveno mjesto $\mathrm{u}$ povijesnim analima. Neki smatraju da je u mnogome zaslužna i za propast Rimskoga carstva. Tijekom povijesti njene žrtve su bili prinčevi, kraljevi i veliki osvajači, a samo je tijekom XX. stoljeća prouzročila smrt između 150 i 300 milijuna ljudi. Drevni spisi i različiti artefakti svjedoče o dugoj vladavini malarije (Carter i Mendis, 2002.). U svojoj knjizi o malariji Chloupek (1939.) opisuje malariju poput najvećeg carstva na svijetu, a takvo malarično carstvo je za čovjeka carstvo tuge i nevolje. Spominje područja Makedonije gdje je službovao nakon Prvog svjetskog rata, gdje je malarija endemska. ,U tim selima ljudi su sivi kao i njihove kuće, žutosivi kao ispržena zemlja. Ako im pogledate $u$ oči, ogledalo duše, onda je ta duša jedna teška patnja“.

Izgradnja Panamskog kanala bila je jedinstven primjer kako bolest može kočiti ljudski napredak. Panamski kanal je bio jedan od najvećih, najambicioznijih i najznačajnijih inženjerskih projekata $\mathrm{u}$ modernoj povijesti. Isto tako, bio je i jedan od najsmrtonosnijih poduhvata na svijetu. Zbog visoke smrtnosti radnika na tome projektu nakon nekoliko godina radovi su obustavljeni. Smatra se da je više od 27000 ljudi umrlo od bolesti i posljedica, a glavni uzrok je bila malarija (Walker, 2014.). Raširenost malarije ovisi o raširenosti vektora, komarca iz roda Anopheles. Čak oko 70 vrsta komaraca toga roda ima sposobnost prenošenja uzročnika malarije (Sinka i sur., 2012.). Kinin je imao važnu ulogu u liječenju različitih groznica i malarije tijekom kolonijalnih osvajanja, i štitio je bijelce koji su se suočavali s tropskim bolestima te je na taj način utjecao na ratne ishode tijekom povijesti (Bruce-Chwatt, 1988., 
Curtin, 1990., Brabin, 2014.). Nakon više od stoljeća od identifikacije parazita uzročnika malarije i više od pola stoljeća nakon pronalaska učinkovitih lijekova i insekticida protiv komaraca, od malarije još uvijek obolijeva 228 milijuna ljudi $\mathrm{u}$ različitim dijelovima svijeta, a 405000 ih umire, osobito $\mathrm{u}$ najsiromašnijim. Malarija je peti uzrok smrti u svijetu (WHO, 2020.a). U mnogim krajevima svijeta malarija je i dalje "kraljica bolesti“, a njezino "carstvo" i dalje traje.

Pjegavi (epidemijski) tifus prouzroči Rickettsia prowazekii koju prenosi prtena uš koja se inficira sišući krv bolesnika u stadiju rikecijemije. Odigrao je ključnu ulogu tijekom ratova u Europi od XV. do XX. stoljeća. Najveća poznata epidemija pjegavog tifusa pratila je Napoleonovu vojsku tijekom vojne invazije na Rusiju. Smatra se da je više od 500000 vojnika umrlo od hladnog vremena i zaraznih bolesti, a jedna od najprisutnijih bolesti bila je pjegavi tifus (Raoult i sur., 2004.). U knjizi Augusta Hirsha iz 1883. godine napisano je: „Povijest tifusa je zapisana kao tamna stranica svjetske priče, koji je čovječanstvo posjećivao tijekom ratova, bijede, patnje i boli svake vrste..." (Snyder, 1947.). Pjegavi tifus se pojavljivao i u izbjegličkim logorima u Burundiju 1997. godine s više tisuća oboljelih, što nas opominje da se može pojaviti kao jedna od katastrofalnih posljedica sloma društvenog sustava (Raoult i sur., 1998.).

Osim pjegavog tifusa, uši prenose i povratnu (rekurentnu) i rovovsku groznicu. Bolesti su poznate stoljećima, a njihova je pojava najizraženija tijekom ratova. One i dalje predstavljaju glavnu brigu javnog zdravstva u populacijama ljudi koji žive u lošim higijenskim uvjetima zbog ratova i različitih društvenih poremećaja, gladi te siromaštva. U razvijenim zemljama bolesti se često dokazuju u beskućnika, a u zemljama u razvoju epidemije ovih bolesti zabilježene su u zatvorima i izbjegličkim logorima (Badiaga i Brougui, 2012.).

\section{Lepra i tuberkuloza}

Dvije važne i nezaobilazne bolesti prouzročene mikobakterijama su tuberkuloza i lepra. Tuberkuloza i lepra pratitelji su ljudskoga roda od prapovijesti pa sve do danas. Mnoge ljudske sudbine bile su povezane s tuberkulozom, a ona je oduvijek bila neizostavni dio života zajednice. Nigdje $u$ drevnim zapisima ne postoji zapis njezina početka, ali kroz povijest uvijek je bila prisutna. Tamo gdje su druge epidemije trajale tjednima ili mjesecima, epidemija tuberkuloze trajala je stoljeće, a i dulje. Tuberkuloza je polako i tiho, puzajući ulazila u domove milijuna ljudi, jednom kad bi stigla i ostala bi. Pogađala je veliki broj ljudi, a vrlo često su to bila djeca i mladi ljudi, na početku svog života, što je imalo široki društveni utjecaj. U XIX. stoljeću se činilo kao da svi umiru od tuberkuloze. Tuberkuloza je postala popularna pojava, prvo kao romantično otkupljenje, a zatim kao odraz društvenih zala (Morens, 2002.). Brojne životne sudbine bile su povezane s tuberkulozom, posvećena su joj djela kroz opise likova ili kroz bolest samog umjetnika. Mnogi pjesnici i slikari umrli su mladi od tuberkuloze, a iza sebe su ostavili veliki opus (Dugac, 2005., Vrga, 2012.). Prema najnovijim podatcima Svjetske zdravstvene organizacije danas u svijetu od tuberkuloze još uvijek umire milijun i pol ljudi, a oboli ih oko deset milijuna (WHO, 2020.b).

Lepra je jedna od najstarijih i najstrašnijih bolesti od koje obolijevaju ljudi. Bila je sinonim za stigmatizaciju i diskriminaciju zbog velikih deformacija na tijelu. Od davnina je poznata kao „smrt prije smrti“. Usprkos terapiji, i dalje je u nekim zemljama endemska (Visschedijk i sur., 2000., Dogra i sur., 2013.). Godišnje se dijagnosticira 200000 novooboljelih od lepre. Prema podatcima SZO u 2015. 
godini lepra je prijavljena u 106 zemalja svijeta, a na svijetu ima oko četiri milijuna ljudi s invaliditetom prouzročenim leprom. Dugo se smatralo da je lepra samo bolest ljudi, ali dokazano je da su prirodni rezervoari lepre devetokolutni pasanci u SAD- u i Južnoj Americi (Truman i sur., 2011.).

\section{Sifilis}

Sifilis je stalni i neželjeni suputnik čovječanstva već više od 400 godina. Od prve pojave sifilis je bila stigmatizirana, sramotna bolest. Utjecao je na živote milijuna ljudi u svim društvenim slojevima. Mnoge poznate osobe, umjetnici, pisci, skladatelji i velike povijesne osobe bile su zaražene sifilisom. Sifilis nije birao razinu socijalnog, društvenog i gospodarskog statusa, od njega su obolijevali svi. Sifilis je bolest sa sto lica i veliki imitator. Ovaj stari neprijatelj čovječanstva za kojeg se nakon otkrića penicilina smatralo da je na rubu poraza, opet iznenađuje te se vraća i dalje pobuđuje pažnju čovječanstva. U posljednjih 30 godina, zbog homoseksualnih navika, zlouporabe droga i HIV infekcije, broj zaraženih je ponovno u porastu, što predstavlja problem javnog zdravstva (Marinović i Lipozenčić, 2002.).

\section{Kolera}

Smatra se da je suvremena povijest kolere započela 1817. godine kada su se pojavile eksplozivne epidemije kolere $\mathrm{u}$ regiji Bengal uz područje rijeke Ganges $\mathrm{u}$ Indijskom potkontinentu, gdje je bolest endemična. To je bila prva od sedam do danas zabilježenih pandemija kolere koje su pogodile skoro cijeli svijet i prouzročile milijune smrtnih slučajeva (Siddique i Cash, 2014.). Epidemije različitih bolesti su tijekom XIX. stoljeća bile vrlo česte, a naročito teško je bilo za vrijeme kolere, koja je prouzročila vrlo visoku smrtnost. Broj umrlih je izazivao veliku paniku, a poseban strah i nevjerica potaknuti su simptomima koji su ljudsko tijelo pretvorili u olupinu, što je ovu bolest učinilo strašnom pošasti od koje su se ljudi užasavali (Ipšić, 2010.). Izbijanje kolere prouzroči ljudsku patnju, paniku, narušavanje društvene i gospodarske strukture te razvoj zajednice gdje god se pojavi. Prirodne katastrofe poput tsunamija, potresa i ratova znatno povećavaju rizik epidemija $\mathrm{s}$ visokim stopama smrtnosti.

\section{COVID-19}

U prosincu 2019. godine u Wuhanu, glavnom gradu provincije Hubei u Kini, počeli su se pojavljivati bolesnici s teškom pneumonijom nepoznatog uzroka. Većina bolesnika imala je zajedničku poveznicu, a to je da su svi bili izloženi lokalnoj tržnici u Huananu. Kina je 31. prosinca 2019. godine obavijestila Svjetsku zdravstvenu organizaciju o izbijanju bolesti, a 1. siječnja tržnica hrane je zatvorena. Već 7. siječnja 2020., virus je identificiran kao koronavirus koji je više od $95 \%$ bio istovjetan s koronavirusom šišmiša i više od $70 \%$ je imao sličnosti s virusom SARS CoV (Singhal, 2020.). Broj oboljelih počeo se eksponencijalno povećavati. Prvi smrtni slučaj prijavljen je 11. siječnja 2020. Masovna migracija Kineza tijekom kineske Nove godine pojačala je epidemiju. Zabilježeni su slučajevi u drugim pokrajinama Kine, a zatim i u drugim zemljama azijskog kontinenta (Tajland, Japan, Južna Koreja). Do 23. siječnja 2020., 11 milijuna stanovnika Wuhana stavljeno je u izolaciju uz velika ograničenja izlaska i ulaska (Huang i sur., 2020.).

Svjetska zdravstvena organizacija (WHO), 30. siječnja 2020., službeno je proglasila epidemiju s COVID-19 od javnog značenja i od međunarodnog interesa. Pojava akutne respiratorne bolesti prouzročena novim koronavirusom (SARS-CoV-2), a nakon SARS-CoV 2002. i MERS-CoV 2012., godine, to je pojava i treće visoko patogene i velike epidemije koranavirusa u ljudsku populaciju u 21. 
stoljeću (Guo i sur., 2020.). U 99 bolesnika s pneumonijom iz Wuhana, u svih je dokazan virus SARS-CoV-2. Njih 49 (49\%) bilo je izloženo morskoj hrani na tržnici u Huananu, a 50 (51 \%) ih je imalo kronične bolesti. U opisu kliničkih znakova većina bolesnika (83\%) je imalo vrućicu, kašalj $82 \%$, kratkoću daha $31 \%$, bol u mišićima $11 \%$, zbunjenost $9 \%$, glavobolju $8 \%$, grlobolju $5 \%$, bol u prsima $2 \%$, proljev $2 \%$ i povraćanje u $1 \%$ bolesnika. Bilateralnu upalu pluća pokazalo je $75 \%$ bolesnika, $17 \%$ bolesnika razvilo je akutni respiratorni distresni sindrom, a u $11 \%$ bolesnika stanje se $\mathrm{u}$ kratkom vremenu pogoršalo i rezultiralo je smrću od zatajenja više organa. Prosječna starost bolesnika iznosila je 55,5 godina, 67 su bili muškarci i 32 žene (Chen i sur., 2020.).

Tijekom siječnja i veljače 2020. bolest se počela pojavljivati u Europi i drugim dijelovima svijeta. U mladića koji je bio na nogometnoj utakmici u Milanu, 26. veljače 2020. dokazan je koronavirus, što je prvi dokazani slučaj bolesti u Hrvatskoj, a 11. ožujka 2020. ministar zdravstva u Republici Hrvatskoj proglašava epidemiju.

\section{Umjesto zaključka}

Vidljivo je da su kroz čitavu povijest zarazne bolesti imale znatan utjecaj na razvoj i prosperitet čovječanstva. Neke bolesti su u razvijenim zemljama suzbijene ili su pod kontrolom, dok u nerazvijenim one i dalje opstaju i od njih obolijevaju milijuni ljudi. Krajem XIX. stoljeću otkriveni su gotovo svi važni uzročnici najvažnijih bakterijskih bolesti, njihov uzgoj i identifikacija. Razvijena su različita cjepiva u kontroli i suzbijanju bolesti kao i različite mjere za kontrolu i prevenciju najvažnijih bolesti. Polovicom XX. stoljeće otkriveni su kemoterapeutici i antibiotici. Moglo se reći da su riješeni gotovo svi praktični problemi u suzbijanju i kontroli zaraznih bolesti koje su se do tada po- javljivale (Brachman, 2003.). Međutim, uspjelo se iskorijeniti velike boginje, a rezultati su razočaravajući u borbi protiv starih povijesnih bolesti poput malarije, kolere ili tuberkuloze koje i dalje predstavljaju problem u većem dijelu nerazvijenog svijeta. Tako da se često ne govori o iskorjenjivanju već samo o nadziranju endemskih bolesti.

Nakon što je primijećena pojava emergentnih i re-emergentnih bolesti Institut za medicinu Nacionalnog vijeća za istraživanje SAD, 1991. godine imenuje devetnaesteročlano multidisciplinarno povjerenstvo za proučavanja pojave novih uzročnika koji su prijetnja zdravlju nacije. Emergentne zarazne bolesti su bolesti koje se po prvi puta pojavljuju $\mathrm{u}$ nekoj populaciji, a re-emergentne su one koje se nakon određenog razdoblja ponovno pojavljuju na neko prostoru gdje su ranije već bile eradicirane. $\mathrm{Nji-}$ hovo izvješće iz 1992., godine imalo je naslov: "Nove zaraze - mikrobna prijetnja $z$ dravlju $S A D^{\prime \prime}$. U cijeloj raspravi došlo se do zaključka da postoji šest različitih čimbenika kojima se može objasniti pojava emergentnih ili re-emergentnih zaraznih bolesti. Ti čimbenici su: ljudska demografija i ponašanje, tehnologija i industrija, gospodarski razvoj i korištenje zemljišta, međunarodna putovanja i trgovina, adaptacija i promjena mikroorganizama te slom mjera javnog zdravstva (Brachman, 2003.). Emergentne zarazne bolesti predstavljaju znatan teret globalnom gospodarstvu i javnom zdravstvu. Između 1940. i 2004. godine pojavile su se 334 emergentne zarazne bolesti u svijetu. Najviša incidencija je bila 1980-tih godina, istodobno s pojavom HIV pandemije. Dominirale su zoonoze $(60,3 \%)$, a većina zoonoza $(71,8 \%)$ potjecala je od divljih životinja. Navodi se da su u 54,3\% slučajeva uzročnici bile bakterije i rikecije, u 25,4 \% uzrok su bili virusi, u 10,7 \% protozoe, u 6,3\% gljivice i u 3,3\% helminti. Vektorskim bolestima pripada $22,8 \%$, a u posljednjim 
desetljećima čak 28,8 \% bolesti (Jones i sur., 2008.).

Početkom XX. stoljeća, 1918. godine virus španjolske gripe harao je svijetom. Različiti, vrlo slični i promijenjeni virusi ptičje gripe (H5N1), virus pandemijske (nove) gripe A (H1N1) ili neki drugi tipovi poput H7N9 i danas unose strah, nemir i smrt u pojedine dijelove svijeta. Godine 1977. Svjetska zdravstvena organizacija objavila je da su pobijeđene velike boginje, virusna bolest koja je tijekom povijesti prouzročila najveći broj smrtnih slučajeva. Međutim, samo nekoliko godina kasnije, tijekom 1980-tih, pojavio se novi virus, virus HIV-a (engl. Human immunodeficency virus) koji je prouzročio AIDS (engl. AIDS - Aquired immunodeficiency syndrome) i koji je svojom pojavom i posljedicama opet prestrašio svijet. To je sindrom stečenog nedostatka imunosti, što dovodi do stanja oslabljene imunosti, a posljedica je pojava različitih bolesti koje se u zdravih ljudi ne bi pojavile. Prema podatcima Svjetske zdravstvene organizacije u svijetu je 2018. godine živjelo s AIDS-om 37,9 milijuna ljudi, 1,7 milijuna je novootkriveno, a 770000 umro je od posljedica bolesti (HZJZ, 2019.). U SAD-u u regiji Four Corners 1993. godine pojavila se bolest slična gripi. U oboljelih se razvila teška upala pluća i došlo je do smrti. Virus je u početku nazvan Sin Nombre (SNV) (španj. bezimeni), kasnije je identificiran hantavirus, a prirodni rezervoar virusa je miš (Peromyscus maniculatus). Bolest je rijetka, ali vrlo ozbiljna i često smrtonosna (čak do 66,7 \%) (Torres-Perez i sur., 2010.). Infekcija hendra virusom je rijetka zoonoza koja prouzroči tešku i često smrtonosnu bolest $\mathrm{u}$ inficiranih konja i ljudi. Virus je prvi puta opisan 1994. godine $u$ Hendri predgrađu Brisbanea $u$ Australiji. Razboljela se kobila sa simptomima sličnim gripi, a od iste bolesti oboljele su dvije osobe, a vlasnik konja je umro od zatajenja pluća i bubrega. U Australiji je opisano više desetaka slučajeva u konja i ljudi. Rezervoari virusa su šišmiši (Field, 2016.). U Maleziji je 1997. godine identificiran encefalitis i respiratorne bolesti u svinja. Ubrzo nakon toga radnici koji su radili na farmi počeli su se razbolijevati od encefalitisa. Tijekom dvogodišnjeg razdoblja bilo je nekoliko stotina slučajeva bolesti u ljudi s više od 100 smrtnih slučajeva. Iz mozga pacijenta koji je umro izdvojen je nipah virus. Radilo se o paramyxovirusu sličnih karakteristika kao i hendra virus, a rezervoar je pronađen $u$ šišmišima iz roda Pteropus koji se hrane voćem (Carter i Saunders, 2007., Ang i sur., 2018.). Virus Zapadnog Nila poznat je još od 1937. godine kada je izdvojen iz krvi žene u području Zapadnog Nila u Ugandi. Godine 1996. godine zabilježene su infekcije u Europi, a 1999. i u SAD-u. Infekcija virusom Zapadnog Nila tipična je zoonoza koju prenose vektori. Većinom prolazi asimptomatski (u $80 \%$ slučajeva), u 20 \% zaraženih infekcija se očituje kao nespecifična febrilna bolest, a u manje od $1 \%$ bolesnika javlja se neuroinvazivna bolest koja se očituje meningitisom i encefalitisom. Različite vrste ptica primarni su domaćini i rezervoari virusa, a glavni vektori su komarci (Carter i Saunders, 2007.).

Početkom XXI. stoljeća, 2003. godine pojavila se u Aziji ptičja gripa uzrokovana podtipom virusa A/H5N1. Tijekom 2009. godine u svijetu se pojavila tzv. svinjska gripa prouzročena H1N1 virusom gripe. Bolest se počela širiti s čovjeka na čovjeka pa je tako poprimila pandemijski potencijal (Savić, 2009.). Prije 17 godina (2002.) u Kini se pojavio SARS, teška virusna respiratorna bolest koja može prouzročiti smrtnost i do $15 \%$ oboljelih ljudi (Krajinović i Baršić, 2003.). Godine 2012. u Saudijskoj Arabiji pojavila se nova globalna prijetnja, bolest nazvana MERS, koja prouzroči tešku respiratornu bolest. Iako je većina pacijenata geografski povezana s arapskim poluotokom, MERS je otkriven i u 
drugim dijelovima svijeta. Domaćini virusa su deve, a dokazan je i interhumani prijenos. Na Srednjem istoku smrtnost je iznosila čak 25,9\%, odnosno $20,4 \%$ u Južnoj Koreji (Park i sur., 2018.). Prema podatcima Svjetske zdravstvene organizacije od 2012. do danas bolest je dokazana u 27 zemalja svijeta. Tijekom 2013. godine svijet je uzbunila pojava strašne virusne bolesti ebole koja se pojavila $u$ zapadnoj Africi. Ugroženi su bili milijuni ljudi, a oboljelo ih je više tisuća. Bolest je zoonoza, a virus je dokazan u gorila, čimpanza, voćnih šišmiša i antilopa (Jemeršić, 2014.).

Povijesno gledano zarazne bolesti imale su duboki utjecaj na ljudsku populaciju, uključujući njezinu evoluciju i razvoj. Pojava bolesti nije jednostavna pojava, ona je dinamična, većina novih bolesti nije prouzročena novim uzročnicima već su oni uglavnom poznati, ali se pojavljuju ponovno u drugačijim okolnostima, na drugi način, a mnoge bolesti promijenile svoju sliku i utjecaj. Javlja se sve veći broj potencijalno patogenih (oportunističkih) mikroorganizama. Lakše se prepoznaju i identificiraju zbog novih i vrlo osjetljivih tehnika kojima se dokazuju. Ljudske aktivnosti pomažu pojavi bolesti, a različiti društveni, gospodarski, politički, klimatski, tehnološki i okolišni čimbenici mogu utjecati i oblikovati njezinu pojavu. Spoznaja da se zarazne bolesti u potpunosti mogu pobijediti, posljednjih je godina pokolebana pojavom emergentnih i re-emergentnih bolesti. Unatoč napretku medicine, znanstvenici još uvijek ne nalaze trajna rješenja u nekim područjima svijeta za dugo nam poznate bolesti poput malarije, tuberkuloze ili kolere. Spektar zaraznih bolesti se širi, a problemi infekcija prisutni su u svim aspektima medicine, sve su složeniji, a izazovi zahtjevniji.

Jasno je da na početku novog tisućljeća zarazne bolest predstavljaju veliku i stalnu prijetnju današnjem društvu. Još su uvijek jedan od najvećih ubojica u svijetu, otprilike oko 15 milijuna lju- di i danas umire zbog zaraznih bolesti. U čovjeku je veliki, možda čak i najveći strah od bolesti. Nobelovac Ivo Andrić je rekao: „Bolest je sirotinjska sudbina, ali i bogataška kazna“. Jer svi se boje bolesti, ali kod ove i mnogih bolesti ranije uvijek najčešće nastradaju bespomoćni, siromašni. Bolesti, glad i bijeda uvijek su pratili siromaštvo. Kako to da još i danas 10 milijuna ljudi obolijeva od tuberkuloze, a 1,5 milijun ih umire?! (WHO, 2020.a). Istraživači su procijenili da svake godine u svijetu ima od 1,3 do 4 milijuna slučajeva kolere i od 21000 do 143000 smrtnih slučajeva, a većina $(80$ $\%)$ se može liječiti samo rehidracijskom otopinom. Samo osiguravanje sigurne, zdrave i pitke vode te sanitarnih uvjeta umnogome rješava pitanje ove povijesne bolesti (Ali i sur., 2015.). Prema podatcima Svjetske zdravstvene organizacije iz 2018., malarija je dokazana u 228 milijuna ljudi diljem svijeta, a 405000 ih je umrlo (WHO, 2020.). Međutim, treba pogledati u kojim se zemljama pojavljuje. Zato i pažnja Zapadnog svijeta nije usmjerena na te probleme.

Pandemija s COVID-19 zahvatila je cijeli svijet i svijet je na koljenima. Ponavlja se fraza: "Svijet više nikada neće biti isti“. Ne mimoilazi ni one bogate i svjetski moćne države ni državnike, poput britanskog premijera Johnsona, princa Charlesa, glumca Toma Hanksa i njegove supruge ili supruge kanadskog premijera Justina Trudeaua te mnoge druge poznate i važne osobe. A taj strah svakako postaje veći i opravdaniji kada i Svjetska zdravstvena organizacija napominje da je čovječanstvo u ozbiljnoj i strašnoj opasnosti od velike pandemije koja nam danas prijeti od COVID-19. Brojni analitičari i eksperti diljem svijeta ovih dana govore o urušavanju zdravstvenog sustava, gospodarstva, naftne industrije, svjetskog BDP-a, burzi, ali malo tko ističe da je na djelu možda generalna proba za buduće urušavanje istrošenog i destruktivnog modela koji pokazuje svoje 
limite. Nije riječ, kako bi htjeli razni katastrofičari i proroci apokalipse, o kraju svijeta, već o kraju jednog svijeta, svijeta neoliberalne hiperglobalizacije, utopijske vjere $u$ vječnu i sretnu globalizaciju i neprestani rast, koji pokazuje svoju definitivnu povijesnu istrošenost (Vujić, 2020.). I kako hrvatski glumac Goran Bogdan $\mathrm{u}$ jednom hrvatskom dnevnom listu kaže: „Virus je dosta komunistički. Svima isto bez obzira na rasu, spol, religiju $i$ status" (Pofuk, 2020.).

\section{Literatura}

1. ALI, M., A. R. NELSON, A. L. LOPEZ and D. A SACK (2015): Updated global burden of cholera in endemic countries. PLoS Negl. Trop Dis. 9 (6): $\mathrm{e} 0003832$.

2. ANG, B. S. P., T. C. C. LIM and L. WANG (2018): Nipah virus infection. J. Clin. Microbiol. 56, 6, e01875-17.

3. Anon. (2006): Enciklopedijski rječnik humanog i veterinarskog medicinskog nazivlja. Hrvatska akademija znanosti i umjetnosti. Bolest, str. 187.

4. ANUŠIĆ, N. (2015): U sjeni velikog rata. Pandemija španjolske gripe 1918. - 1919. u sjevernoj Hrvatskoj. Srednja Europa, Zagreb.

5. BADIAGA, S. and P. BROUQUI (2012): Human louse-transmitted infectiuous diseases. Clin. Microb. Infect. 18, 332-337.

6. BEHBEHANI, A. M. (1983): The smallpox story: life and death of an old disease. Microbiol. Rev. 47, 455-509.

7. BRABIN, B. J. (2014): Malaria's contribution to World War One - the unexpected adversary. Malaria Journal 13, 2-22.

8. BRACHMAN, P. S. (2003): Infectious diseases - past, present and future. Int. J. Epidemiol. 32, 684-686.

9. BRUCE-CHWATT, L. J. (1988): Cinchona and its alkaloids: 350 years later. NY State. J. Med. 88, 318-322.

10. CARTER, R. and K. N. MENDIS (2002): Evolutionary and historical aspects of the burden of malaria. Clin. Microbiol. Rev. 15, 564-594.

11. CARTER, J. and W. A. SAUNDERS (2007): Hendra virus, Nipah virus. In: Virology, John Wiley \& sons, Ltd. Chuchester, West susex, England. P. 275.

12. CHEN, N., M. ZHOU, X. DONG, J. QU, F, GONG, Y. HAN, Y. QUI, J. WANG, Y. LIU, Y. WEI, J. XIA, T. YU, X. ZHANG and L. ZHANG (2020): Epidemiological and clinical characteristics of 99 cases of 2019 novel coronavirus pneumonia in Wuhan, China: a descriptive study. Lancet 395, 507-513.
13. CHLOUPEK, D. (1939): Malarija. Škola narodnog zdravlja, Zagreb.

14. CVETNIĆ, Ž. (2014): Kuga - bolest koja je promijenila svijet (I. dio). Vet. stn. 45, 85-95.

15. CVETNIĆ, Ž. (2019): Bolesti koje su promijenile svijet. Medicinska naklada/Hrvatski veterinarski institut.

16. CURTIN, P. D. (1990): The end of the "white man's grave"? Nineteenth-century mortality in West Africa. J. Interdisciplin. His. 21, 663-688.

17. ČOBELJIĆ, M. (2004): Smallpox outbreak in Yugoslavia in 1972. Vojnosanit. Pregl. 61, 569-571.

18. DODIG, S. (2016): Biblijska medicina - o zdravlju, bolesti i smrti u Bibliji. Medicinska naklada, Zagreb. Bolest, str. 49-123.

19. DUGAC, Ž. (2005): Zdravstveno prosvjećivanje protiv tuberkuloze u međuratnoj Hrvatskoj. Medicus 14, 155-171.

20. DOGRA, S., T. NARANG and B. KUMAR (2013): Leprosy - evolution of the part to eradication. Indian J. Med. Res. 137, 15-35.

21. ERKOREKA, A. (2009): Origins of the Spanish influenza pandemic (1918-1920) and its relation to the First World War. J. Mol. Gen. Med. 3, 190-194.

22. FIELD, H. E. (2016): Hendra virus ecology and transmission. Curr. Opin. Virol. 16, 120-125.

23. FODOR, A. (1894): Kr. zem. zavod za proizvodnju animalnog cjepiva protiv boginja. Liječnički viestnik 12, 226-230.

24. GLESINGER, L. (1978): Povijest medicine. Školska knjiga, Zagreb.

25. GRMEK, M. D. (2000): Život, bolesti i povijest. Hrvatska akademija znanosti i umjetnosti, Zagreb.

26. GUO, Y. R., Q. D. CAO, Z. S. HONG, Y. Y. TAN, S. D. CHEN, H. J. JIN, K. S. TAN, D. Y. WANG and Y. YAN (2020): The origin, transmission and clinical therapies on coronavirus diseases (COVID-19) outbreak - an update on the status. Mil. Med. Res. 7, 11, doi. 10.1186/s40779-020-00240-0.

27. HUANG, C., Y. WANG, X. LI, et al. (2020): Clinical features of patients infected with 2019 novel coronavirus in Wuhan, China. Lancet 395, 497-506.

28. HZJZ (2019): Svjetski dan AIDS-a 2019. https:// www.hzjz.hr./služba-promicanja-zdravlja/. Objavljeno 26. studenog 2019. Pristupljeno 11. 04. 2020.

29. IPŠIĆ, I. (2010): Demografske i društvenogospodarska posljedica epidemija kolere: primjer epidemije u Drenovcima 1873. godine. Scrinia slavonica 10, 527-545

30. JEMERŠIĆ, L. (2014): Ebola - zoonoza čija nam pojava stalno prijeti. Vet. stn. 45, 297-305.

31. JONES, K. E., N. G. PATEL, M. A. LEVY, A STOREYGARD, D. BALK, J. L. GITTLEMAN and P. DASZAK (2008): Global trends in emerging infectious diseases. Nature 451, 990-993. 
32. KOLATA, G. (2001): Flu-the story of the great influenza pandemic of 1918 and the search for the virus that causet it. Touchstone Edition, New York.

33. KRAJINOVIĆ, V. and B. BARŠIĆ (2003): Teški akutni respiratorni sindrom (SARS). Medix 51, 35-37.

34. KULJIĆ-KAPULJICA, N. (2004): Variola - prošlost ili ne? Srp. Arh. Celok. Lek. 132, 272-276.

35. MAREVIĆ, J. (2000): Latinsko-hrvatski enciklopedijski rječnik. Matica Hrvatska, Zagreb. Morbus, str. 1965.

36. MARINOVIĆ, B. and J. LIPOZENČIĆ (2002): Where does syphilis stand in Croatia? Clin. Dermatol. 20, 141-146.

37. MEYER, K. F. (1961): Plague. In: Hull, T. G.: Diseases transmitted from animals to man. Springfield, Ilinois (USA). Pp. 467-508.

38. MLINARIĆ-GALINOVIĆ, G. (2013): Poksvirusi. U: Kalenić i sur. Medicinska mikrobiologija. Medicinska naklada. Zagreb. Str. 387-391.

39. MORENS, D. (2002): At the deathbed of consuptive art. Emer. Inf. Dis. 8, 1353-1358.

40. MORSE, S. S. (2009): Emerging infections: Condemned to repeat? In: Relman, D. A., M. A. Hamburg, R. A. Choffnes, A. Mack: Microbial evolution and co-adaption: A tribute to the life and scientific legacies of Joshua Lederberg. National Academies Press, Washington, DC.

41. MUSLIĆ, LJ. (2020): Psihološki aspekti pojave koronavirusa: Kako se nositi sa strahom? http:/ www.hzjz.hr./priopčenje-mediji/objavljeno 11.03.2020. Pristupljeno 11. 04. 2020.

42. NALCA, A. and E. E. ZUMBRUNE (2010): ACAM2000TM. The new small vaccine for United States Strategic National Stockpile. Drug. Des. Devel. Ther. 4, 71-79.

43. NIKIĆ, M. (1994): Psihologija straha. Obnov. život. 49, 43-67.

44. PARK, J. E., S. JUNG, A. KIM and J. E. PARK (2018): MERS transmision and risk factors: a systematic review. BMC Public Health 18:574.doi.org/10.1186/ s12889-018-5484-8.

45. POFUK, B. (2020): Intervju - Goran Bogdan. Večernji list, 11. travnja 2020.

46. RAKOVAC, L. (1896): Eduard Jenner cijepio je prvi put sadržajem kravljih boginja dne 14. svibnja 1796. Liječnički vjesnik 5, 113-118.

47. RAOULT, D., J. B. NDIHOKUBWAYO, H. TISSOTDUPONT, V. ROUX, B. FAUGERE, R. ABEGBINNI and R. J. BIRTLES (1998): Outbreak of epidemic typhus associated with trench fever in Burundi. Lancet 352, 353-358.

48. RAOULT, D., T. WOODWARD and S. DUMLER (2004): The history of epidemic typhus. Infect. Dis. Clin. N. Am. 18, 127-140.
49. SAVIĆ, V. (2009): Nova - stara svinjska gripa. Vet. stn. 40, 129-131.

50. SHCHELKUNOV, S. N. (2013): An increasing danger of zoonosis Orthopoxvirus infection. Plos Patholog. 9 (12).e1003756. DOI.10.1371/journal. ppat.1003756.

51. SIDDIQUE, A. K. and R. CASH (2014): Cholera outbreaks in the classical botype era. Curr. Top Microbiol. Immunol. 379, 1-16.

52. SINGHAL, T. (2020): A Review of Coronavirus Disease-2019 (COVID-19). Indian. J. Pediatr. 87, 281-286.

53. SINKA, M. E., M. J. BANGS, S. MANGUIN et al. (2012): A global map of dominant malaria vectors. Paras. Vect. 5, 69. doi.org/10.1186/1756-3305-5-69.

54. SNYDER, J. C. (1947): Typhus fever in the Second World War. Cal. Med. 66, 3-10.

55. TAUBENBERGER, J. K. and D. M. MORENS (2006): 1918 Influenza: the mother of all pandemics. Emerg. Infect. Dis. 12, 15-22.

56. THEVES, C., P. BIAGINI and E. CRUBEZY (2014): The rediscovery of smallpox. Clin. Microbiol. Infect. 20, 210-218.

57. TORRES-PEREZ, F., L. WILSON, S. K. COLLINGE, H. HARMON, C. RAY, R. A. MEDINA and B. HJELLE (2010): Sin Nombre virus infection in field workers, Colorado, USA. Emerg. Infect. Dis. 16, 308-310.

58. TRUMAN, R. W., P. SINGH, R. SHARMA, P. BUSSO, J. ROUGEMONT, A. PANIZ-MODOLFI, A. KAPOOULOU, S. BRISSE, D. M. SCOLLARD, T. P. GILLIS and S. COLE (2011): Probable zoonotic leprosy in the Sothern United States. N. Engl. J. Med. 364, 1626-1633.

59. VISSCHEDIJK, J. J., H. VAN DE BROEK, H. EGGENSE, P. LEVER, S. VAN BEERS and P. KLATSER (2000): Review: Mycobacterium leprae - millenium resistant! Leprosy control on the threshold of new era. Trop. Med. Int. Health 5, 388-399.

60. VUJIĆ, J. (2020): Koronavirus ili kraj sretne globalizacije. Vijenac - Društvo 680. Matica Hrvatska. Izdanje od 26. ožujka 2020.

61. VRGA, B. (2012): Tuberkuloza i likovnost. Vlastita naklada, Petrinja.

62. WALKER, A. (2014): 10 of History's deadliest construction projects - Panama Canal, 1888-1914. https://gizmodo.com/10-of-historys-deadliestconstruction-projects-1588099877.

63. WHO (2020a): Malaria. https://www.who.int./ malaria. Pristupljeno 11. 04. 2020.

64. WHO (2020b): Tuberculosis. https://www.who.int/ health-topics/tuberculosis. Pristupljeno 11. 04. 2020. 


\section{Fear of disease and death - from the variola virus once to COVID-19 today}

Željko CVETNIĆ, DVM, PhD, Academician, Croatian Veterinary Institute, Veterinary Department Križevci, Križevci, Croatia

Throughout history, diseases have had a major impact on the development and prosperity of humankind. They arouse attention due to their mass occurrence, high mortality rates among the affected, and the far-reaching consequences caused. Due to the fear of loss of health and life, illness and death have always been an essential preoccupation for humans. During the past, great epidemics have decided the fate of individual nations, weakened the strength of large and powerful armies, caused hunger and misery. Epidemics of smallpox, plague, malaria, syphilis, cholera, epidemic typhus, and tuberculosis have marked history and been a constant companion to human suffering over many centuries. At the beginning of the $20^{\text {th }}$ century there was the Spanish flu, called the "mother of all pandemics", and by the end of the century, the appearance of AIDS frightened the world.
It is clear that even in the new millennium, disease poses a strong and constant threat to society and continues to be one of the greatest killers in the world, with approximately 15 million people per year dying of infectious diseases today. The rapid appearance of the COVID-19 pandemic, the largest epidemic in the $21^{\text {st }}$ century, has brought the world to its knees. Even wealthy nations and statesmen have not been bypassed. This fear is certainly becoming more justified with the assessment of the World Health Organization that humanity is in grave and terrible danger. One thing is certain: the occurrence of an epidemic prompts us to think deeply about the future, which quickly becomes uncertain, all plans disrupted, and goals shifted and slowed.

Key words: disease; death; epidemic; variola virus; COVID-19 